\title{
Age, growth and mortality of the cichlid fish Oreochromis niloticus (L.) from the River Nile at Beni Suef Governorate, Egypt.
}

\author{
Adel A. Hassan ${ }^{1}$ and Midhat A. El-Kasheif ${ }^{2}$ \\ 1- Zoology Department, Faculty of Science, Ain Shams University,Cairo, Egypt. \\ E-mail: e_adelali@yahoo.com \\ 2- National Institute of Oceanography and Fisheries, Cairo, Egypt.
}

\section{ABSTRACT}

Monthly samples of Oreochromis niloticus from the River Nile at Beni Suef were collected during the period from January 2009 to December 2010. The Von Bertalanffy growth function parameters were: $\mathbf{L}_{\infty}=48.14 \mathrm{~cm}, \mathrm{~K}=0.147 \mathbf{y r}^{-\mathbf{1}}$, and $\mathbf{t}_{\mathbf{0}}$ $=0.2237$ year. The total mortality coefficient $(\mathrm{Z})$ was calculated as $0.9654 \mathbf{y r}^{\mathbf{- 1}}$, the natural computed mortality coefficient (M) was $0.4010 \boldsymbol{y r}^{-\mathbf{1}}$ with fishing mortality (F) estimated as $0.5643 \mathbf{y r}^{-\mathbf{1}}$ and exploitation ratio (E) calculated as 0.5819. This high exploitation ratio shows that the stock of Oreochromis niloticus from the River Nile at Beni Suef is overexploited.

Keywords: Cichlid, Oreochromis niloticus, Egypt, fisheries, mortality.

\section{INTRODUCTION}

The cichlid fishes are the most common and economically important components of the tropical fresh and brackish waters. The studied species, Oreochromis niloticus, which is abundantin in all Egyptian inland waters is tasty and inexpensive. It constitutes most of the commercial catch from the River Nile at Beni Suef Governorate.

Many authors paid their attention for the biological and fishery studies of tilapia species from different water bodies all over the world especially in Egypt. From these studies are those of Moreau et al. (1986); Bayoumi and Khalil (1988); Abdel-Aziz et al. (1990); Yamaguchi et al. (1990); El-Haweet (1991); Getabu (1992); El-Shazly (1993); Abd-Alla (1995); Shenouda et al. (1995); Gomez-Marquez (1998); Abd-Alla and Talaat (2000); Khalifa et al. (2000); Akel (2005); Akel and Moharram (2007); and El-Ganainy and Hassan (2008). The present study is the first trial to have a complete biological study on this important tilapia species from the main River Nile at Beni Suef Governorate.

\section{MATERIALS AND METHODS}

A sum of 1405 specimens of Oreochromis niloticus were collected in a random way from the commercial catches of the main landing site on the River Nile at Beni Suef during the period from January 2009 to December 2010. After recording the date of capture, the following measurements were taken for each fresh specimen: total length; total weight; and sex. Some scales were collected from underneath the right pectoral fin of each specimen and kept in special envelops for further investigation. The scales were then dipped in 5\% neutral Formalin solution, washed in distilled water and pressed in between two glass slides. The scales were then examined under a compound Nikon light microscope with an eye piece micrometer. The total scale 
radius " $\mathrm{R}$ " and the radius of each annulus " $\mathrm{r}$ " were measured to the nearest 0.01 micrometer divisions (m.d.).

The water temperature was measured from four different localities on the River Nile at Beni Suef in all months of the years 2009 and 2010 using a mercuric thermometer.

The length-weight relationship for both sexes combined of Oreochromis niloticus were computed by the least squares and the geometric regression methods using the Microsoft Office Excell 2007 program. This program also calculates the composite "K" and relative " $\mathbf{K}_{\mathbf{n}}$ " coefficients of condition.

For the back calculation of body length at the end of each year of life, the equation of Lee (1920) was used. These results should be incorporated in the Von Bertalanffy (1938) mathematical model of growth. The constants of the Von Bertalanffy equation ( the asymptotic length " $\mathbf{L}_{\infty}$ " and the growth coefficient "K") were calculated by using three different fitting methods ( Ford,1933-Walford,1946; Gulland and Holt, 1959; and Chapman, 1960). The empirical equation of Pauly (1979) was used to estimate the hypothetical age $\left(\mathbf{t}_{\mathbf{0}}\right)$ of the fish, which is the age at zero length. The reliability of these growth parameters was tested using the Munro's phi prime index $(\varnothing)$ computed from the equation derived by Pauly and Munro (1984):

$$
\emptyset=\log _{10} \mathrm{~K}+2 \log _{10} \mathbf{L}_{\infty}
$$

The survival rate "S", the instantaneous total mortality coefficient "Z" and the annual mortality coefficient "A" of Oreochromis niloticus were estimated using four different methods ( Heinke,1913; Jackson,1939; Chapman and Robson,1960; and coded mean age). The instantaneous rate of natural mortality coefficient "M" was estimated from the empirical equation of Pauly (1980) using the mean annual water temperature of the River Nile at Beni Suef as measured in the present study (Table 1) being $21.5^{\circ} \mathrm{C}$. The instantaneous rate of fishing mortality " $\mathrm{F}$ " was calculated as $\mathrm{F}=$ Z-M. The exploitation ratio "E" was calculated as the fraction of death caused by fishing $E=F / Z$.

Table 1: Mean Monthly and annual water temperature in $\left({ }^{\circ} \mathrm{C}\right)$ recorded from four different localities on the River Nile at Beni Suef .

\begin{tabular}{|l|c|c|c|c|c|c|c|c|}
\hline \multirow{2}{*}{ Month } & \multicolumn{5}{|c|}{ Year 2009 } & \multicolumn{4}{c|}{ Year 2010 } \\
\cline { 2 - 10 } January & Loc.1 & Loc.2 & Loc.3 & Loc.4 & Loc.1 & Loc.2 & Loc.3 & Loc.4 \\
\hline February & 14.9 & 15.4 & 15.1 & 15.4 & 15.6 & 15.5 & 15.8 & 15.5 \\
\hline March & 14.8 & 14.5 & 14.0 & 13.8 & 17.3 & 16.8 & 16.9 & 17.0 \\
\hline April & 16.7 & 16.7 & 16.8 & 16.3 & 19.4 & 19.6 & 19.5 & 19.5 \\
\hline May & 19.4 & 19.6 & 19.7 & 20.7 & 21.1 & 20.9 & 20.8 & 21.0 \\
\hline June & 22.3 & 21.6 & 21.9 & 21.8 & 22.2 & 21.8 & 22.4 & 22.2 \\
\hline July & 22.6 & 21.9 & 22.7 & 22.5 & 24.5 & 24.8 & 24.7 & 24.6 \\
\hline August & 26.8 & 26.2 & 26.7 & 26.5 & 29.5 & 30.2 & 31.3 & 29.8 \\
\hline September & 27.4 & 27.5 & 27.2 & 27.7 & 27.6 & 28.0 & 27.8 & 27.5 \\
\hline October & 25.8 & 25.5 & 25.6 & 25.6 & 25.8 & 26.0 & 25.7 & 25.8 \\
\hline November & 24.8 & 25.1 & 25.0 & 24.7 & 24.6 & 24.5 & 24.7 & 24.6 \\
\hline December & 21.3 & 21.1 & 20.9 & 21.0 & 20.3 & 19.7 & 19.7 & 19.9 \\
\hline $\begin{array}{l}\text { Mean annual temp } \\
\text { Mean total annual } \\
\text { temp }\end{array}$ & 17.1 & 17.5 & 17.6 & 17.2 & 15.4 & 15.3 & 14.9 & 15.1 \\
\hline \multicolumn{7}{|l|}{$21.1^{\circ} \mathrm{C}$} \\
\hline
\end{tabular}




\section{RESULTS AND DISCUSSION}

\section{A) Time of annulus formation:}

The time of the annulus formation of Oreochromis niloticus was estimated as the time of the least distance from the last annulus to the scale margin for a certain age group. Table (2) shows the mean distance from the last annulus to the scale margin at different months for age group (I) of Oreochromis niloticus. From this table it is expected that the least increment occurred during February (0.429 m.d.). However, this result did not reflect the actual time of annulus formation. It is well known that Oreochromis niloticus in the River Nile has two main spawning periods, the first being in April and the second being in September. As it is clear from Table (2), the differences between the results obtained for all months were not clearly significant, except in June, which may reflect more than two spawning periods. So, it is expected that the water temperature is the only factor affecting the annulus formation.

Table 2: Mean distance from the last annulus to the scale margin at different months for age group ( I ) of Oreochromis niloticus.

\begin{tabular}{|l|c|c|}
\hline $\begin{array}{c}\text { Month } \\
\text { of capture }\end{array}$ & $\begin{array}{c}\text { Number of } \\
\text { ishes }\end{array}$ & $\begin{array}{c}\text { Mean distance from the last annulus to scale margin in } \\
\text { (m.d.) for age group (III) }\end{array}$ \\
\hline January & 22 & 0.586 \\
February & 37 & 0.429 \\
March & 35 & 0.483 \\
April & 31 & 0.590 \\
May & 46 & 0.490 \\
June & 41 & 1.035 \\
July & 79 & 0.518 \\
August & 46 & 0.548 \\
September & 48 & 0.563 \\
October & 35 & 0.601 \\
November & 44 & 0.431 \\
December & 35 & 0.503 \\
\hline
\end{tabular}

\section{B ) Growth in length:}

\section{Body length- scale radius relationship:}

The total body length and scale radius relationship of Oreochromis niloticus is graphically represented by the scattered diagram in Fig. (1). It is represented by a straight line not passing through the origin. Thus the constants "a" and "b" of the straight line were calculated using the least squares method. This relationship is expressed by the following equation:

$$
\mathrm{L}=-0.6772+0.2351 \mathrm{R}
$$

With a high correlation coefficient of 0.961 .

\section{Back calculation of body length at the end of each year of life:}

As the body length-scale radius relationship of Oreochromis niloticus was found to be linear and does not pass through the origin, therefore the following equation was adopted in back-calculation:

$$
\mathbf{L}_{\mathbf{n}}=\frac{(\mathbf{L}-\mathbf{a}) \mathbf{r}_{\mathbf{n}}}{\mathbf{R}}+\mathbf{a} \quad \text { Lee (1920) }
$$

where $\left(\mathbf{L}_{\mathbf{n}}\right)$ is the fish length at the time of formation of the $\mathrm{n}^{\text {th }}$ annulus, $(\mathrm{L})$ is the fish length at capture , $\left(\mathbf{r}_{\mathbf{n}}\right)$ is the radius of the $\mathrm{n}^{\mathrm{th}}$ annulus, $(\mathrm{R})$ is the total scale radius and (a) is the intercept of the regression line with the $\mathrm{Y}$ axis in the body length-scale radius relationship. 


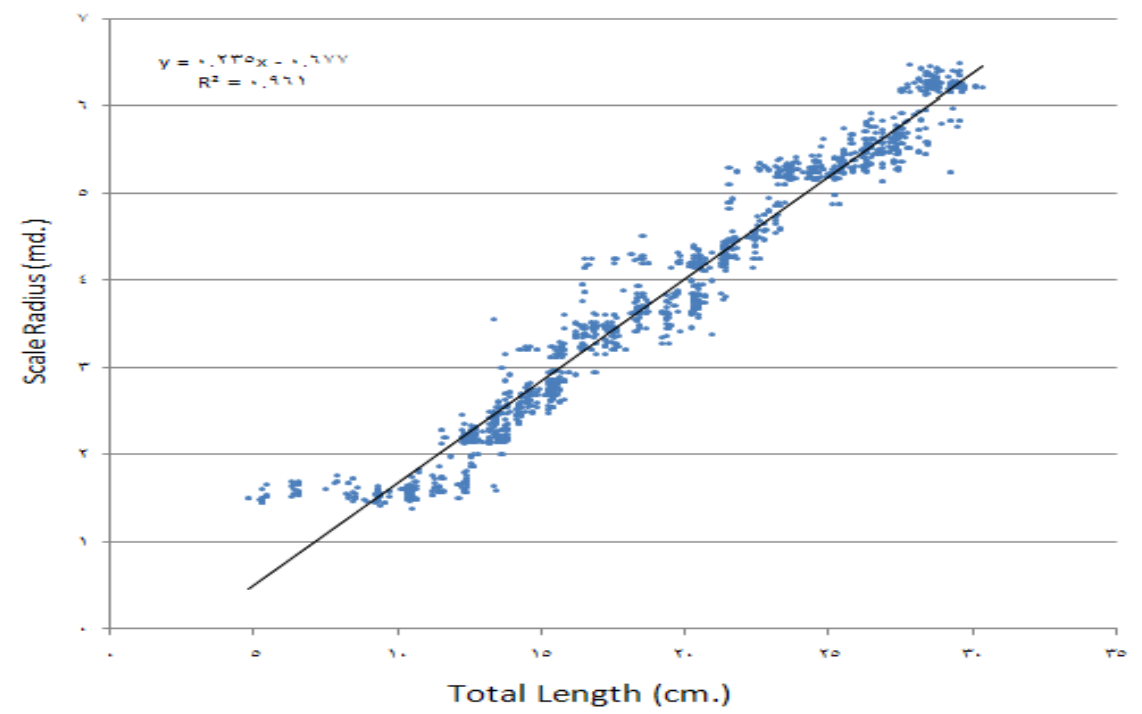

Fig. 1: Total length - scale radius relationship of Oreochromis niloticus on normal coordinates (the straight line represents the calculated values and the dots represent the observed ones ).

Table (3) shows the mean back-calculated lengths at the end of the different years of life, while Table (4) shows the length increments. From Table (3) it is obvious that the growth in length is more rapid in earlier age groups. The highest estimated length increment was attained at the first year of life $(16.13 \mathrm{~cm}$.$) , which$ differs from that obtained by El-Ganainy and Hassan (2008) which was $(11.07 \mathrm{~cm})$.

Table 3: Mean back calculated total lengths in $(\mathrm{cm}$.$) at the end of different years of life of Oreochromis$ niloticus.

\begin{tabular}{|c|c|c|c|c|c|}
\hline \multirow{2}{*}{ Age group in years } & \multirow{2}{*}{ Frequency } & \multicolumn{4}{|c|}{ Mean calculated total lengths (cm.) at the end of each year of life } \\
\cline { 3 - 6 } & & 1 & 2 & 3 & 4 \\
\hline I & 499 & 16.13 & & & \\
II & 237 & 16.27 & 21.32 & & \\
III & 109 & 15.88 & 21.13 & 25.01 & 28.50 \\
IV & 2 & 17.80 & 23.84 & 25.64 & \\
\hline
\end{tabular}

Table 4: Calculated lengths (cm.) and length increments of Oreochromis niloticus at the end of different years of life.

\begin{tabular}{|c|c|c|c|}
\hline Years of life & Frequency & Calculated length $(\mathrm{cm})$. & Length increment $(\mathrm{cm})$. \\
\hline I & 499 & 16.13 & 2.67 \\
II & 237 & 21.32 & 5.19 \\
III & 109 & 25.01 & 3.69 \\
IV & 2 & 28.50 & 3.43 \\
\hline
\end{tabular}

In the present study, scales show that there are four age groups for Oreochromis niloticus, which differs from that of El-Ganainy and Hassan (2008), in this study of length frequency distribution, there are five age groups. These differences are expected as the water condition in Beni Suef seems to be more suitable for cichlids than the water in Timsah Lake.

\section{Length-weight relationship:}

The total length $(\mathrm{cm}$.$) and the total weight (gm.) relationship of Oreochromis$ niloticus can be expressed by the power equation: $\mathbf{W}=\mathrm{a} \mathbf{L}^{\mathbf{n}}$ (Ricker,1975), where (a and $n$ ) are constants computed by the least squares and the geometric regression 
methods (Table 5). The equations representing this relationship by the two fitting methods are:

$$
\begin{array}{cc}
\mathrm{W}=1.3771 \times \mathbf{L}^{\mathbf{2 . 7 5 5 5}} & \text { (Least squares method) } \\
\text { and } \mathrm{W}=0.0377 \times \mathbf{L}^{\mathbf{2 . 7 9 2 4}} & \text { (Geometric regression method) }
\end{array}
$$

Table 5: The constants of the length-weight relationship of Oreochromis niloticus for both sexes combined.

\begin{tabular}{|c|c|c|}
\hline & Least squares method & Geometric regression method \\
\hline $\mathrm{a}$ & 1.3771 & 0.0377 \\
\hline $\mathrm{n}$ & 2.7555 & 2.7924 \\
\hline & 0.9471 & 0.9516 \\
\hline Average weight in gm. & 137.80 & \\
Average length in cm. & 16.93 & \\
$\mathrm{~N}$ & 1405 & \\
\hline
\end{tabular}

"a and n" : the constants for the length - weight equation.

$\mathrm{W}=\mathrm{aL}^{\mathrm{n}} \mathrm{gm}, / \mathrm{cm}$. ;

$\mathbf{R}^{2}$ correlation coefficient.

$\mathrm{N}$ : Number of fish.

There is a close agreement between the observed and the calculated weights for both sexes combined which is clear in Table (6) and graphically represented in Figs. (2 \& 3).

Table 6: Mean observed and calculated weights of Oreochromis niloticus for both sexes combined.

\begin{tabular}{|c|c|c|c|c|c|}
\hline \multirow{2}{*}{ Total length in cm. } & \multirow{2}{*}{ No. of fishes } & \multicolumn{3}{|c|}{ Total weight in gm. } \\
\cline { 4 - 5 } Range & \multirow{2}{*}{ Mean } & & Observed & \multicolumn{2}{|c|}{ Calculated } \\
\cline { 4 - 5 } & & Mean & Least squares & Geometric regression \\
\hline $4-5.9$ & 5.24 & 14 & 9.41 & 4.03 & 3.85 \\
\hline $6-7.9$ & 6.74 & 21 & 12.29 & 8.06 & 7.78 \\
\hline $8-9.9$ & 8.98 & 39 & 15.49 & 17.78 & 17.31 \\
\hline $10-11.9$ & 10.77 & 90 & 25.96 & 29.51 & 28.75 \\
\hline $12-13.9$ & 13.02 & 199 & 50.08 & 48.98 & 48.84 \\
\hline $14-15.9$ & 15.08 & 189 & 75.44 & 74.13 & 73.61 \\
\hline $16-17.9$ & 16.94 & 121 & 86.53 & 102.33 & 101.85 \\
\hline $18-19.9$ & 18.88 & 100 & 125.43 & 138.04 & 137.86 \\
\hline $20-21.9$ & 20.87 & 171 & 169.56 & 181.97 & 182.38 \\
\hline $22-23.9$ & 23.04 & 104 & 245.16 & 239.88 & 240.40 \\
\hline $24-25.9$ & 25.05 & 99 & 323.80 & 302.00 & 303.65 \\
\hline $26-27.9$ & 26.90 & 132 & 413.44 & 363.08 & 370.49 \\
\hline $28-29.9$ & 28.85 & 123 & 514.47 & 446.68 & 450.46 \\
\hline $30-31.9$ & 30.10 & 2 & 502.00 & 501.19 & 507.10 \\
\hline $32-33.9$ & 33.60 & 1 & 768.00 & 676.08 & 689.43 \\
\hline & & & & & \\
\hline
\end{tabular}




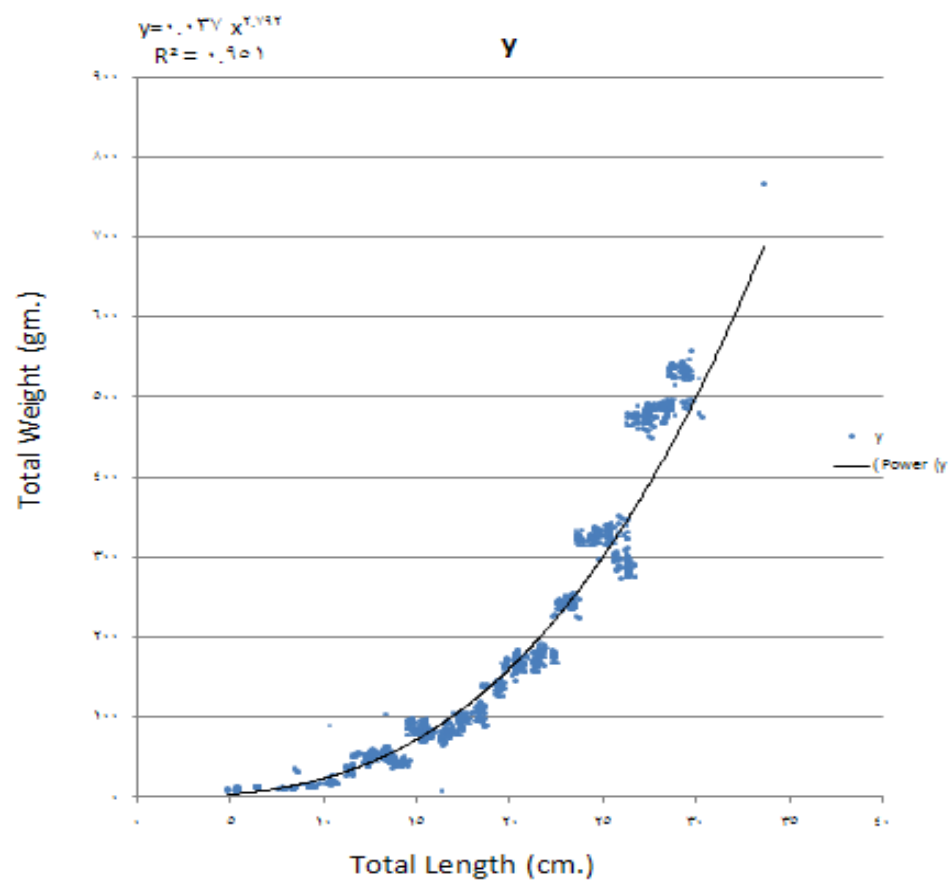

Fig. 2: Length-weight relationship of Oreochromis niloticus on normal coordinates. (The smooth curve represents the calculated values and the dots represent the observed ones).

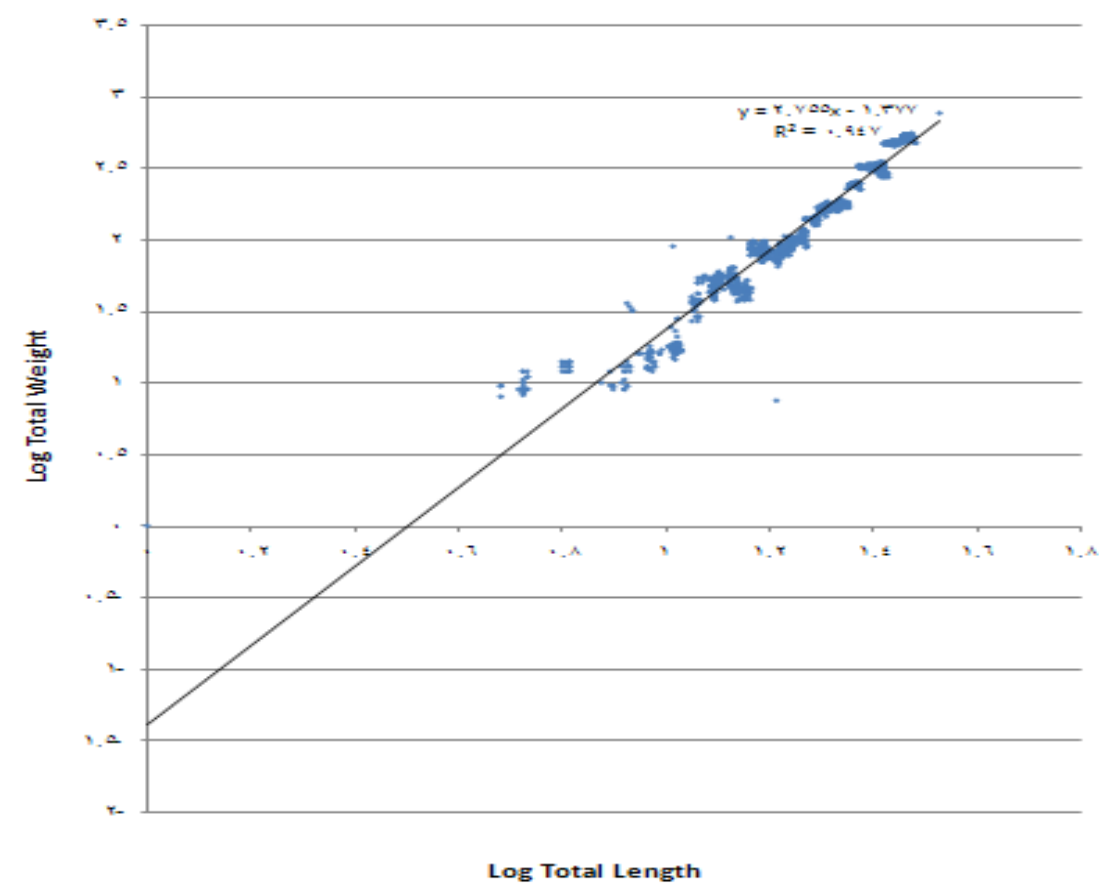

Fig. 3: Total length-total weight relationship of Oreochromis niloticus on logarithmic coordinates (The straight line represents the calaulated weights and the dots represent the observed ones).

\section{Coefficient of condition:}

The coefficient of condition is the degree of well being of fish in numerical terms. The following methods were used to calculate the coefficient of condition:

i- Fulton's coefficient of condition " $K$ ":

$$
\mathrm{K}=100 \mathrm{~W} / \mathbf{L}^{\mathbf{3}} \quad \text { (Hile, 1936) }
$$

where $(\mathrm{W})$ is the observed weight in gm. And (L) is the length in $(\mathrm{cm})$. ii- Relative coefficient of condition " $\mathbf{K}_{\mathbf{n}}$ ": 


$$
\begin{array}{ll}
\text { or } \quad \mathbf{K}_{\mathbf{n}}=\mathrm{W} / \mathrm{a} \mathbf{L}^{\mathbf{n}} \\
\mathbf{K}_{\mathbf{n}}=\mathrm{W} / \mathrm{W}
\end{array}
$$

where (W`) is the calculated weight using the length-weight relationship.

The calculated $\mathrm{K}$ and $\mathbf{K}_{\mathbf{n}}$ for both sexes combined of Oreochromis niloticus for each $2 \mathrm{~cm}$. length interval are given in Table (7). It shows a general trend towards the decrease in the values of $K$ and $\mathbf{K}_{\mathbf{n}}$ in higher length groups. The average monthly $\mathrm{K}$ and $\mathbf{K}_{\mathbf{n}}$ are shown in Table (8) where it shows that the lowest values of $\mathrm{K}$ and $\mathbf{K}_{\mathbf{n}}$ were reported during the winter season (November, December, January and February). On the other side, the highest values were recorded during the summer season (April, May, June, July and August) where fishes are more active. This may explain the differences in age groups between the present study and that of ElGanainy and Hassan (2008), and also explains the highest value of the mean distance from the last annulus to the scale margin being in June.

Table 7: Average composite "k", and relative "kn" coefficients of condition of Oreochromis niloticus for the different length groups between 4 and $34 \mathrm{~cm}$. for both sexes combined.

\begin{tabular}{|c|c|c|c|c|}
\hline \multicolumn{2}{|c|}{ Total length group (cm.) } & \multirow{2}{*}{ No. of fishes } & \multicolumn{2}{|c|}{ Coefficients of condition } \\
\cline { 4 - 5 } Range & Mean & & K & kn \\
\hline $4-5.9$ & 5.24 & 14 & 1.58 & 1.46 \\
\hline $6-7.9$ & 6.74 & 21 & 1.87 & 1.67 \\
\hline $8-9.9$ & 8.98 & 39 & 1.68 & 1.91 \\
\hline $10-11.9$ & 10.77 & 90 & 1.90 & 1.87 \\
\hline $12-13.9$ & 13.02 & 199 & 1.30 & 1.64 \\
\hline $14-15.9$ & 15.08 & 189 & 1.18 & 1.01 \\
\hline $16-17.9$ & 16.94 & 121 & 1.77 & 1.85 \\
\hline $18-19.9$ & 18.88 & 100 & 1.25 & 1.90 \\
\hline $20-21.9$ & 20.87 & 171 & 1.07 & 1.93 \\
\hline $22-23.9$ & 23.04 & 104 & 1.19 & 1.01 \\
\hline $24-25.9$ & 25.05 & 99 & 1.07 & 1.07 \\
\hline $26-27.9$ & 26.90 & 132 & 1.11 & 1.14 \\
\hline $28-29.9$ & 28.85 & 123 & 1.14 & 0.99 \\
\hline $30-31.9$ & 30.10 & 2 & 1.04 & 1.11 \\
\hline $32-33.9$ & 33.60 & 1 & 1.03 & \\
\hline
\end{tabular}

Table 8: Monthly variation in the average composite coefficient of condition " $K$ ” and " $\mathbf{K}_{\mathbf{n}}$ ” for both sexes combined of Oreochromis niloticus.

\begin{tabular}{|l|l|l|l|}
\hline Month & No. of fishes & $\mathrm{K}$ & $\mathbf{K}_{\mathbf{n}}$ \\
\hline January & 66 & 1.04 & 1.00 \\
\hline February & 102 & 1.07 & 1.00 \\
\hline March & 101 & 1.26 & 1.07 \\
\hline April & 98 & 1.56 & 1.23 \\
\hline May & 125 & 1.74 & 1.98 \\
\hline June & 127 & 1.83 & 1.71 \\
\hline July & 216 & 1.61 & 1.82 \\
\hline August & 130 & 1.56 & 1.74 \\
\hline September & 129 & 1.20 & 1.04 \\
\hline October & 104 & 1.13 & 1.02 \\
\hline November & 98 & 1.10 & 1.01 \\
\hline December & 109 & 1.15 & 1.04 \\
\hline
\end{tabular}

\section{Growth in weight:}

Table (9) shows the estimated weight of Oreochromis niloticus at the end of the different years of life which were calculated by applying the length-weight equation for both sexes combined (by the geometric regression method) to the back- 
calculated lengths of Table (2). Table (10) shows the calculated weights and weight increments in the different years of life. Tables ( $9 \& 10)$ show that the growth in weight is slower in earlier age groups, and then increased in the following years of life. The highest weight increment was attained at the $4^{\text {th }}$ year $(133.06 \mathrm{gm}$.), while the least increment was attained by the end of the first year (88.83 gm.).

Table 9: Calculated total weights in gm at the end of the different years of life of Oreochromis niloticus.

\begin{tabular}{|c|c|c|c|c|c|}
\hline \multirow{2}{*}{ Age in years } & \multirow{2}{*}{ Frequency } & \multicolumn{4}{|c|}{ Calculated total weights (gms,) at the end of each year of life } \\
\cline { 3 - 6 } & & 1 & 2 & 3 & 4 \\
\hline I & 499 & 88.83 & & & \\
\hline II & 237 & 91.00 & 193.57 & & \\
\hline III & 109 & 85.04 & 188.80 & 302.30 & \\
\hline IV & 2 & 116.95 & 264.44 & 324.04 & 435.36 \\
\hline
\end{tabular}

Table 10: Calculated weights in gm and weight increments of Oreochromis niloticus at the end of the different years of life.

\begin{tabular}{|c|c|c|c|}
\hline Year of life & Frequency & Weight (gm.) & Weight increment (gm.) \\
\hline I & 499 & 88.83 & 88.83 \\
II & 237 & 193.57 & 104.74 \\
III & 109 & 302.30 & 108.73 \\
IV & 2 & 435.36 & 133.06 \\
\hline
\end{tabular}

\section{Mathematical models of growth:}

The results of scales and the back-calculation of body lengths at different ages should be incorporated in mathematical models to have a generalized form of growth description Free of errors. From these models are those of Gompertz (1825), the logistic model (Verhulst,1845 and Winsor, 1932) and the most common model of Von Bertalanffy (1938). The linear growth length equation of Von Bertalanffy is:

$$
\mathbf{l}_{\mathbf{t}}=\mathbf{L}_{\infty}\left(\mathbf{l}-\mathbf{e}^{-\mathbf{K}\left(\mathbf{t}-\mathbf{t}_{\mathbf{0}}\right)}\right)
$$

where $\left(\mathbf{l}_{\mathbf{t}}\right)$ is the length at age " $t$ ", $\left(\mathbf{L}_{\infty}\right)$ is the asymptotic length when $t \rightarrow \infty,(K)$ is a constant and $\left(\mathbf{t}_{\mathbf{0}}\right)$ is the age at which the length is theoretically nil.

The Von Bertalanffy growth in weight equation was obtained by applying the length-weight equation ( $\mathrm{W}=\mathrm{a}^{\mathbf{n}}$ ) to the growth in length equation as follows:

$$
\mathbf{W}_{\mathbf{t}}=\mathbf{W}_{\infty}\left(1-\mathbf{e}^{-\mathbf{K}\left(\mathbf{t}-\mathbf{t}_{\mathbf{0}}\right)}\right)^{\mathbf{n}}
$$

The constants of the Von Bertalanffy equation $\left(\mathbf{L}_{\infty}, \mathrm{K}\right.$ and $\mathbf{t}_{\mathbf{0}}$ ) were calculated by using Ford (1933)-Walford (1946), Gulland and Holt (1959) and Chapman (1960) fitting methods.

\section{i- Theoretical growth in length:}

The Von Bertalanffy model was used to estimate the theoretical growth in length of Oreochromis niloticus from Beni Suef. Table (11) shows the constants of the Von Bertalanffy computed by the different methods, as well as the growth performance index $(\varnothing)$. The different Von Bertalanffy theoretical growth in length equations are:

$$
\begin{array}{lr}
\mathbf{l}_{\mathbf{t}}=48.14\left(1-\mathbf{e}^{-\mathbf{0 . 1 4 7}(\mathbf{t}-\mathbf{0 . 2 2 3 7})}\right) & \text { Ford-Walford fitting } \\
\mathbf{l}_{\mathbf{t}}=52.33\left(1-\mathbf{e}^{-\mathbf{0 . 1 2 8}(\mathbf{t}-\mathbf{0 . 1 1 4 6})}\right) & \text { Gulland and Holt fitting } \\
\mathbf{l}_{\mathbf{t}}=48.14\left(1-\mathbf{e}^{-\mathbf{0 . 1 4 7}(\mathbf{t}-\mathbf{0 . 2 2 3 7})}\right) & \text { Chapman fitting }
\end{array}
$$


Table 11: The constants of the Von Bertalanffy equation and the phiprime index of Oreochromis niloticus with different fitting methods.

\begin{tabular}{|c|c|c|c|}
\hline $\begin{array}{c}\text { Mehod } \\
\text { Constant }\end{array}$ & Ford Walford & Gulland and Holt & Chapman \\
\hline $\mathrm{L}_{\infty}$ & $\mathbf{4 8 . 1 4}$ & 52.33 & $\mathbf{4 8 . 1 4}$ \\
$\mathrm{K}$ & $\mathbf{0 . 1 4 7}$ & $\mathbf{0 . 1 2 8}$ & $\mathbf{0 . 1 4 7}$ \\
$\mathrm{t}_{\mathbf{0}}$ & $\mathbf{0 . 2 2 3 7}$ & $\mathbf{0 . 1 1 4 6}$ & $\mathbf{0 . 2 2 3 7}$ \\
$\varnothing$ & 2.532 & 2.544 & 2.532 \\
\hline
\end{tabular}

The observed and calculated lengths of Oreochromis niloticus using the above equations are given in Table (12). The estimated growth parameters and the growth performance index $(\varnothing)$ of the studied species compared with those computed in other Egyptian and African lakes are given in Table (13). There is an agreement to some extent between the different results.

Table 12:The observed and calculated lengths of Oreochromis niloticus using Von Bertalanffy equation.

\begin{tabular}{|c|c|c|c|c|}
\hline Age in years & $\begin{array}{c}\text { Mean observed } \\
\text { lengths }\end{array}$ & \multicolumn{3}{|c|}{ Calculated length using Von Bertalanffy equation } \\
\cline { 3 - 5 } & $\begin{array}{c}\text { Ford-Wallford } \\
\text { method }\end{array}$ & $\begin{array}{c}\text { Gulland and } \\
\text { Holt method }\end{array}$ & Chapman method \\
\hline I & 18.85 & 16.13 & 16.16 & 16.13 \\
II & 24.81 & 20.51 & 20.51 & 20.51 \\
III & 28.69 & 24.29 & 24.33 & 24.29 \\
IV & 31.60 & 27.55 & 27.69 & 27.55 \\
\hline
\end{tabular}

Table 13: The estimated growth parameters of Oreochromis niloticus from different localities in different studies.

\begin{tabular}{|l|l|l|l|l|}
\hline \multicolumn{1}{|c|}{ Locality } & \multicolumn{1}{c|}{$\mathbf{L}_{\infty}$} & \multicolumn{1}{c|}{ K } & \multicolumn{1}{c|}{$\emptyset$} & \multicolumn{1}{c|}{ Author } \\
\hline Lake Nasser & 46.2 & 0.546 & 3.07 & Moreau et al. (1986) \\
\hline Lake Mariout & 29.4 & 0.594 & 2.71 & Moreau et al. (1986) \\
\hline Lake Manzala & 29.4 & 0.294 & 2.41 & Moreau et al. (1986) \\
\hline Nozha Hydrodome & 32.6 & 0.356 & 2.58 & Moreau et al. (1986) \\
\hline High Dam Lake Female & 36.9 & 0.545 & 2.87 & Yamaguchi et al. (1990) \\
\hline High Dam Lake Male & 42.8 & 0.384 & 2.85 & Yamaguchi et al. (1990) \\
\hline Lake Victoria & 64.6 & 0.254 & 3.025 & Getabu (1992) \\
\hline Mexico & 29.19 & 0.070 & --- & Gomez-Marquez (1998) \\
\hline Lake Timsah & 28.73 & 0.46 & 2.58 & El-Ganainy and Hassan (2008) \\
\hline River Nile Beni Suef & 48.14 & 0.15 & 2.532 & Present study \\
\hline
\end{tabular}

\section{ii- Theoretical growth in weight:}

The growth in weight equations of Von Bertalanffy by the different fitting methods of Oreochromis niloticus from Beni Suef are given here:

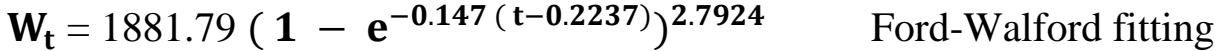

$$
\begin{aligned}
& \mathbf{W}_{\mathbf{t}}=2375.64\left(1-\mathbf{e}^{-\mathbf{0 . 1 2 8}(\mathbf{t}-\mathbf{0 . 1 1 4 6})}\right)^{\mathbf{2 . 7 9 2 4}} \quad \text { Gulland and Holt fitting } \\
& \mathbf{W}_{\mathbf{t}}=1881.79\left(1-\mathbf{e}^{-\mathbf{0 . 1 4 7}(\mathbf{t}-\mathbf{0 . 2 2 3 7})}\right)^{\mathbf{2 . 7 9 2 4}} \quad \text { Chapman fitting }
\end{aligned}
$$

\section{C) Mortality:}

The survival rate "S", the instantaneous rate of total mortality coefficient " $Z$ " and the annual rate of mortality coefficient "A" of Oreochromis niloticus from Beni Suef were computed using four different methods (Heinke,1913; Jackson,1939; Chapman and Robson, 1960; and coded mean age). Table (14) shows that the four methods give nearly the same values of "S", "Z" and "A". 
Pauly (1980) suggested the following equation for the estimation of the natural mortality coefficient "M":

$$
\text { Ln } \mathrm{M}=-0.0066-0.279 \operatorname{Ln} \mathbf{L}_{\infty}+0.6543 \mathrm{Ln} \mathrm{K}+0.6434 \mathrm{Ln} \mathrm{T}
$$

where " $\mathbf{L}_{\infty}$ " and "K" are the constants of the Von Bertalanffy model and " $T$ " is the mean annual water temperature. Table (1) shows that the mean annual water temperature from the River Nile at Beni Suef was recorded to be $21.5{ }^{\circ} \mathrm{C}$ during the years 2009 and 2010. Then "M" for Oreochromis niloticus can be calculated as:

Ln $\mathrm{M}=0.0066-0.279$ Ln $48.14+0.6543$ Ln $0.147+0.6434$ Ln 21.5

Then $\mathrm{M}=0.4010$ year $^{\mathbf{- 1}}$.

The fishing mortality coefficient "F" of Oreochromis niloticus was calculated using the following formula: $F=Z-M$. Table (14) shows that " $F$ " ranges between 0.4862 and 0.6417 year $^{-1}$ with a mean of 0.5644 for the four different fitting methods.

Table 14: The survival rates "S", the instantaneous total mortality coefficients " $\mathrm{Z}$ " , the annual mortality rates "A", the instantaneous rate of fishing mortality " $F$ " and the exploitation ratio "E" of Oreochromis niloticus by the different fitting methods.

\begin{tabular}{|c|c|c|c|c|c|}
\hline $\mathrm{Method}_{\text {Mether }}$ Parameter & "S" & "Z" & "A" & $\begin{array}{c}" F^{\prime \prime} \\
(\mathrm{Z}-\mathrm{M})\end{array}$ & $\begin{array}{c}\text { "E" } \\
(\mathrm{F} / \mathrm{Z})\end{array}$ \\
\hline Heinke (1913) & 0.4109 & 0.8894 & 0.5891 & 0.4884 & 0.5491 \\
\hline Jackson (1939) & 0.4118 & 0.8872 & 0.5882 & 0.4862 & 0.5480 \\
\hline Chapman \& Robson (1960) & 0.3527 & 1.0421 & 0.6473 & 0.6411 & 0.6152 \\
\hline Coded mean age & 0.3525 & 1.0427 & 0.6475 & 0.6417 & 0.6154 \\
\hline Mean & 0.3820 & 0.9654 & 0.6180 & 0.5643 & 0.5819 \\
\hline
\end{tabular}

This fishing mortality coefficient corresponds to an exploitation ratio "E" of: E $=\mathrm{F} / \mathrm{Z}$. Table (14) also shows that "E" ranges between 0.5480 and 0.6154 with a mean of 0.5819. Gulland (1971) found that the optimum exploitation ratio of fish $\mathbf{E}_{\text {opt. }}=$ 0.5. This indicates that the stocks of Oreochromis niloticus from the River Nile at Beni Suef are overexploited and its fishery needs some management regulations (such as reducing the number of Fishing boats and increasing the mesh-size) for improving its production. These results agree with those of El-Ganainy and Hassan (2008) on the same species from Lake Timsah.

\section{REFERENCE}

Abd-Alla, A. (1995): Age, growth and population dynamics of tilapia species in the Egyptian inland waters, Lake Edku. Ph.D Thesis submitted to Sohag Fac. Of Sci. Assuit University.

Abd-Alla, A. and K.M. Talaat (2000): Growth and dynamics of Tilapias in Edku Lake, Egypt. Bull. Nat. Inst. Oceanogr. \& Fish., A. R. E., 26: 183-196.

Abdel-Aziz, E.H.; A.A. Ezzat and M.A. El-Bassir (1990): Growth assessment of cichlid fish, Oreochromis niloticus (L.) from the Egyptian and Sudanese inland waters. Pro. Int. Symp. Biol. And Cult. of Tilapias. Oct. 1990, Alex. Egypt.

Akel, E.H.Kh. (2005): Growth, mortalities and yield per recruit of Tilapia zilli (Gervais) (Pisces, Fam. Cichlidae) from Abu Kir Bay-Eastern Alexandria, Egypt. J. Egypt. Acad. Soc. Environ. Develop., 6(3): 17-31.

Akel, E.H.Kh. and S.G. Moharram (2007): Reproductive Biology of Tilapia zilli (Gerv., 1848) from Abu Kir Bay, Egypt. Egypt. J. Aqua. Res., 33(1): 379-394. 
Bayoumi, A.R. and M.T. Khalil (1988): Tilapia fisheries in Lake Manzala. Egypt. Bull. Nat. Inst. Oceanogr. \& Fish., A. R. E., 14(3): 87-99.

Chapman, D.G. (1960): Statistical problems in dynamics of exploited fisheries populations. Proc. $4^{\text {th }}$ Berkeley Sym. Math. Statist. Probl. 4:153-168.

Chapman, D.G. and D.S. Robson (1960): The analysis of a catch curve. Biometrics, 16: 334-368.

El-Ganainy, A.A. and A.A. Hassan (2008): Biology and fishery of two cichlid species (Oreochromis niloticus and Oreochromis aureus) from Lake Timsah, Egypt. 9(2): 93-103.

El-Haweet, A.A.K. (1991): Biological studies of some cichlid species in Lake Borollus. M.Sc. Thesis submitted to Fac. Sci. Alex. University.

El-Shazly, A. (1993): Biological studies on four cichlid fishes (Tilapia nilotica, Tilapia galilae, Tilapia zilli and Tilapia aurea). M.Sc. Thesis, Fac. Sci. Zagazig University, Egypt.

Ford, E. (1933): An account of the herring investigation conducted at Plymouth during the years from 1924-1933. J. Mar. Biol. Ass. U.K., 19: 305-384.

Getabu, A. (1992): Growth parameters and mortality in Oreochromis niloticus (Linnaeus) from Nyanza Gulf, Lake Victoria. Hydrobiologia, 232(1): 91-97.

Gomez-Marquez, J.L. (1998): Age and growth of Oreochromis niloticus (Perciformes: Cichlidae) in Mexico. Revista de Biologia Tropical, 46(4): 929936.

Gompertz, B. (1825): On the nature of the function expressive of the law of human mortality. Phil. Trans. R. Soc., 36: 513-585.

Gulland, J.A. (1971): The fish resources of the ocean. FAO Fish Tech. Pap. (79):425p.

Gulland, J.A. and S.J. Holt (1959): Estimation of growth parameters for data at unequal time intervals. J. Cons. Ciem., 25(1): 17-91.

Heincke, F. (1913): Investigation on the plaice, general report. 1. The plaice fishery and protective measures. Preliminary brief summary of the most important points of the report. Rapp. P. V., Cons. Int. Explor. Mer., 16: 1-67.

Hile, R. (1936): Age and growth of the cisco Leveichthys artedi (Le Sueur), in the lakes of the north-eastern high lands. Wisconsin. Bull. Mar. Fish., U.S., 48(19): 211-317.

Jackson, C.H.N. (1939): The analysis of an animal population. J. Anim. Ecol., 8: 238246.

Khlifa, U.S.A., M.Z. Agaypi, and H.A. Adam (2000): Population dynamics Oreochromis niloticus L. and Sarotherodon galilaeus Art. 97-90. In: Sustainable fish production in Lake Nasser: Ecological basis and management policy. J. F. (ed). ICLARM Conf. Proc., 61: 184p.

Le Cren, E.D. (1951): The length-weight relationship and seasonal cycle in gonad weight and condition in the perch (Perca fluviatilis). J. Anim. Ecol., 20(2): 201219.

Lee, R.M. (1920): A review of the methods of age and growth determination in fishes by means of scales. Fish. Invest. Min. Agr. Fish., Ser. (2), 4(2): 1-32.

Pauly, D. (1979): Theory and management of tropical multispecies stocks: a review with emphasis on the Southeast Asian demersal fisheries. ICLARM stud. Rev., (1): 35 p.

Pauly, D. (1980): On the interrelationships between natural mortality, growth parameters and mean environmental temperature in 175 fish stocks. J. Cons. Ciem. 39(3): 175-192. 
Ricker, W.E. (1975): Computation and interpretation of biological statistics of fish population. Bull. Fish. Res. Bd. Can., 191: 382p.

Shenouda, T.S., M.E. Azim, F.F. Abbas and E.A. Adam (1995): Comparative age and growth studies on two tilapia species from the High Dam Lake within twenty years and signs of their overfishing. J. Egypt. Ger. Soc. Zool., 18(B): 15-44.

Verhulst, P.F. (1845): Recherches mathemateques sur la loi d'acroissement de la population. Nouv. Nem. Acad. Roy. Soc. et Belles letters, Bruxelles, 18: 1-38.

Von Bertalanffy, L. (1938): A quantitative theory of organic growth. Hum. Biol., 10: 181-213.

Walford, L.A. (1946): A new graphic method on describing the growth of animals. Biol. Bull., 90: 141-147.

Winsor, C.P. (1932): A comparison of certain symmetrical growth curves. J. Wash. Acad. Sci., 22(4): 73-84.

Yamaguchi, Y., N. Hirayama, A. Koike and H.A. Adam (1990): Age determination of growth of Oreochromis niloticus and Sarotherodon galilaeus in High Dam Lake, Egypt. Nippon Suisan Gakkaishi, 56(3): 437-443.

\section{ARABIC SUMMARY}

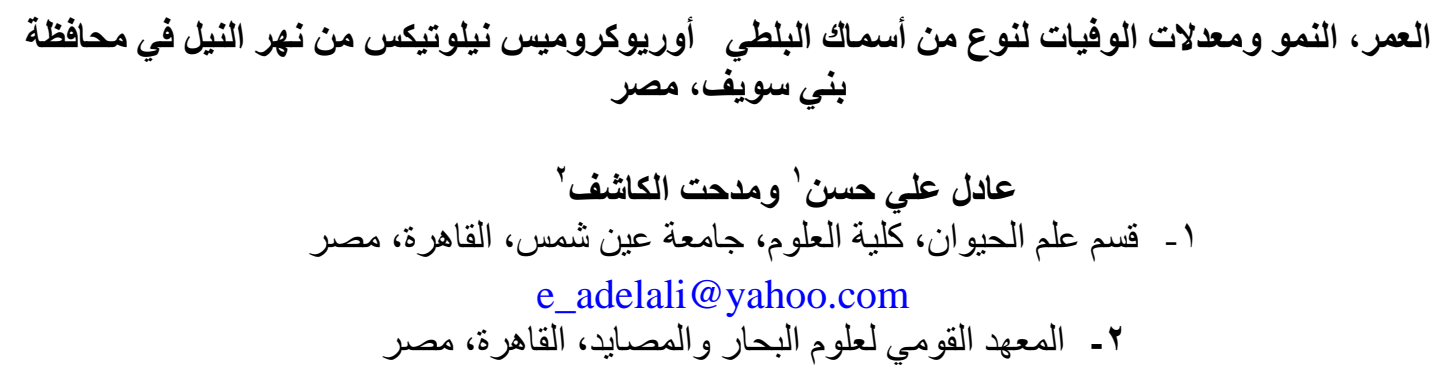

لقد تمت دراسة المعايير العشائرية لنوع هام من أسماك البلطي و هو أوريوكروميس نبلوتيكس من نهر

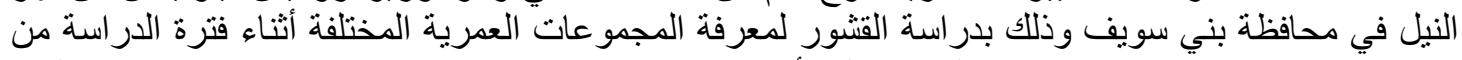

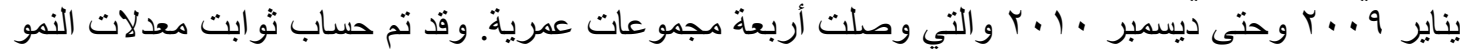
لفونبرتلانفي وكانت على النحو التالي : $\boldsymbol{L}_{\infty}=48.14 \mathrm{~cm}, \mathrm{~K}=0.147 \mathbf{y r}^{-\mathbf{1}}$, and $\mathbf{t}_{\mathbf{0}}=0.2234$ year.

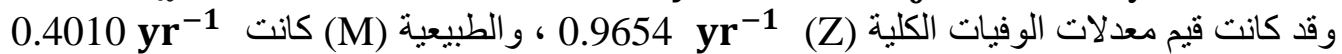

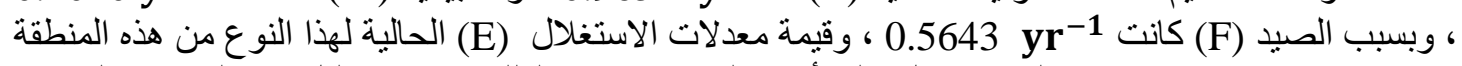

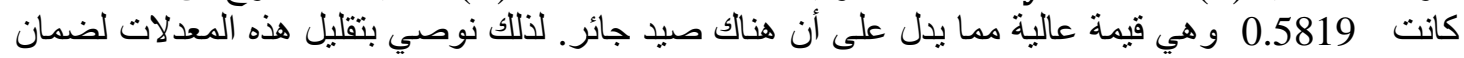
الحصول على إنتاجية عالية من هذه السمكة الاقتصادية الهامة. 